\title{
Improvement Compressive Strength of Cementitious Composites in Different Curing Media by Incorporating $\mathrm{ZrO}_{2}$ Nanoparticles
}

\author{
Mohammad Hossein Rafieipour $^{\mathrm{a}}$, Ali Nazari ${ }^{\mathrm{b} *}$, Mohammad Ali Mohandesi $^{\mathrm{a}}$, Gholamreza Khalaj ${ }^{\mathrm{b}}$ \\ a Department of Civil Engineering, Saveh Branch, Islamic Azad University, Saveh, Iran \\ ${ }^{\mathrm{b}}$ Department of Materials Engineering, Saveh Branch, Islamic Azad University, Saveh, Iran
}

Received: September 29, 2010; Revised: September 24, 2011

\begin{abstract}
In the present work, the effect of curing medium on microstructure, physical, mechanical and thermal properties of $\mathrm{ZrO}_{2}$ nanoparticles blended concrete has been investigated. $\mathrm{ZrO}_{2}$ nanoparticles were partially used instead of cement by $0.5,1.0,1.5$ and 2.0 weight percent. Curing of the specimens was carried out in water and saturated limewater for 7, 28 and 90 days. The results indicate that $\mathrm{ZrO}_{2}$ nanoparticles up to maximum of $2.0 \%$ produces cementitious composite with improved compressive strength by curing in saturated limewater. The optimum level of replacement for the specimens cured in water was 1.0 weight percent. $\mathrm{ZrO}_{2}$ nanoparticles can improve the filler effects and also the high activity of fine particles substantially increases the quantity of strengthening gel. Although the limewater reduces the strength of concrete without nanoparticles when compared with the specimens cured in water, curing the specimens in saturated limewater results in more strengthening gel formation around $\mathrm{ZrO}_{2}$ nanoparticles blended concrete causes high strength.
\end{abstract}

Keywords: $\mathrm{ZrO}_{2}$ nanoparticle, compressive strength, setting time, cementitious composite, curing medium, limewater, workability, TGA, XRD, pore structure

\section{Introduction}

There are several reports on merging nanoparticles in concrete specimens which most of them have focused on using $\mathrm{SiO}_{2}{ }^{[1-16]}$ and $\mathrm{TiO}_{2}$ nanoparticles ${ }^{17-19}$.

$\mathrm{SiO}_{2}$ nanoparticles have been found to improve concrete strength $^{2,9,11}$, to increase resistance to water permeability ${ }^{12}$, and to help control the leaching of calcium ${ }^{13}$, which is closely associated with various types of concrete degradation. $\mathrm{SiO}_{2}$ nanoparticles, in addition, have been shown to promote the hydration reactions of $\mathrm{C}_{3} \mathrm{~S}$ as a result of the large and highly reactive surface of the nanoparticles ${ }^{10,14} \cdot \mathrm{SiO}_{2}$ nanoparticles have been found to be more efficient in enhancing strength than silica fume ${ }^{15,16}$. Adding $10 \% \mathrm{SiO}_{2}$ nanoparticles with dispersing agents has been observed to increase the compressive strength of cementitious composites at 28 days by as much as $26 \%$, compared to only a $10 \%$ increase with adding $15 \%$ silica fume ${ }^{10}$. Even the addition of small amounts of $\mathrm{SiO}_{2}$ nanoparticles has been observed to increase the strength results in improving the 28 day compressive strength by $10 \%$ and flexural strength by $25 \%{ }^{[2]}$. However, these results depend on the production route and conditions of synthesis of $\mathrm{SiO}_{2}$ nanoparticles (e.g., molar ratios of the reagents, the type of reaction media, and duration of the reaction for the sol-gel method) and that dispersion of $\mathrm{SiO}_{2}$ nanoparticles in the paste plays an important role. $\mathrm{SiO}_{2}$ nanoparticles not only behaved as nanofiller to improve the microstructure but also as an activator to accelerate pozzolanic reactions ${ }^{15}$.

Incorporating $\mathrm{TiO}_{2}$ nanoparticles has been addressed in some of the works considering the properties of NVCs.

*e-mail: alinazari84@aut.ac.ir
The flexural fatigue performance of concrete containing $\mathrm{TiO}_{2}$ nanoparticles for pavement has experimentally been studied by Li et al. ${ }^{17}$. They showed that the flexural fatigue performance of concretes containing $\mathrm{TiO}_{2}$ nanoparticles is improved significantly and the sensitivity of their fatigue lives to the change of stress is also increased. In addition, the theoretic fatigue lives of concretes containing $\mathrm{TiO}_{2}$ nanoparticles are enhanced in different extent. With increasing stress level, the enhanced extent of theoretic fatigue number is increased ${ }^{17}$. The abrasion resistance of concrete containing $\mathrm{TiO}_{2}$ nanoparticles for pavement has been experimentally studied ${ }^{18}$. The abrasion resistance of concretes containing $\mathrm{TiO}_{2}$ nanoparticles is significantly improved. The enhanced extent of the abrasion resistance of concrete is decreased by increasing the content of $\mathrm{TiO}_{2}$ nanoparticles ${ }^{18}$. The hydration kinetics of titania-bearing tricalcium silicate phase has been studied ${ }^{19}$. Nano- $\mathrm{TiO}_{2}-$ doped tricalcium silicate $\left(\mathrm{C}_{3} \mathrm{~S}\right)$ was obtained by repeated firing of calcium carbonate and quartz in the stoichiometric ratio of 3:1 in the presence of varying amounts of titanium dioxide from 0.5 to $6 \%$ by weight. The study revealed that the presence of up to $2 \% \mathrm{TiO}_{2}$ has an inhibiting effect on the rate of hydration of $\mathrm{C}_{3} \mathrm{~S}^{[19]}$.

In addition, some of the works have conducted on utilizing nano- $\mathrm{Al}_{2} \mathrm{O}_{3}{ }^{[17,18]}$, nano- $\mathrm{Fe}_{2} \mathrm{O}_{3}{ }^{[19]}$ and zinc-iron oxide nanoparticles ${ }^{20}$.

The other nanoparticles (such as $\mathrm{ZrO}_{2}$ nanoparticles in this work) have rarely investigated and some of researchers do not agree that the other nanoparticles could be pozzolans. It seems that several works are needed to introduce these new materials as partial cement replacement. 
Table 1. Chemical and physical properties of Portland cement (Wt\%).

\begin{tabular}{cccccccccc}
\hline Material & $\mathbf{S i O}_{2}$ & $\mathrm{Al}_{2} \mathbf{O}_{3}$ & $\mathbf{F e}_{2} \mathbf{O}_{3}$ & $\mathbf{C a O}$ & $\mathbf{M g O}$ & $\mathbf{S O}_{3}$ & $\mathbf{N a}_{2} \mathbf{O}$ & $\mathbf{K}_{2} \mathbf{O}$ & Loss on ignition \\
\hline Cement & 21.89 & 5.3 & 3.34 & 53.27 & 6.45 & 3.67 & 0.18 & 0.98 & 3.21 \\
\hline Specific gravity: $1.7 \mathrm{~g} . \mathrm{cm}^{-3}$. & & & & & & & &
\end{tabular}

In our previous works ${ }^{20-38}$, the effects of different nanoparticles on physical and mechanical properties of concrete specimens have been studied. In this work, the influence of nano- $\mathrm{ZrO}_{2}$ on compressive strength and physical, thermal and microstructural properties of binary blended cementitious composite cured in water and saturated limewater has been investigated.

\section{Materials and Methods}

Ordinary Portland Cement (OPC) conforming to ASTM $\mathrm{C} 150^{[39]}$ standard was used as received. The chemical and physical properties of the cement are shown in Table 1.

Nano- $\mathrm{ZrO}_{2}$ with average particle size of $15 \mathrm{~nm}$ producing from Suzhou Fuer Import\&Export Trade Co., Ltd was used as received. The properties of nano- $\mathrm{ZrO}_{2}$ particles are shown in Table 2.

Locally available natural sand with particles smaller than $0.5 \mathrm{~mm}$ and fineness modulus of 2.25 and specific gravity

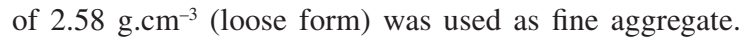
Crushed basalt stored in the laboratory with maximum size of $15 \mathrm{~mm}$ and specific gravity of $2.96 \mathrm{~g} . \mathrm{cm}^{-3}$ (loose form) was used as coarse aggregate.

Two series of mixtures were prepared in the laboratory trials. C0 Series mixtures were prepared as control specimens. The control mixtures were made of natural aggregates, cement and water. $\mathrm{N}$ series were prepared with different contents of nano- $\mathrm{ZrO}_{2}$ particles with average particle size of $15 \mathrm{~nm}$. The mixtures were prepared with the cement replacement of $0.5,1.0,1.5$ and $2.0 \%$ by weight. The water to binder ratio for all mixtures was set at 0.40 . The aggregates for the mixtures consisted of a combination of crushed basalt and of fine sand, with $30 \mathrm{wt} \%$ of sand. The binder content of all mixtures was $450 \mathrm{~kg} \cdot \mathrm{m}^{-3}$. The proportions of the mixtures are presented in Table 3.

$\mathrm{N}$ series mixtures were prepared by mixing the course aggregates, fine aggregates and powder materials (cement and nano- $\mathrm{ZrO}_{2}$ particles) in a laboratory concrete drum mixer. The powder material in the $\mathrm{C} 0$ series mixtures was only cement. They were mixed in dry condition for two minutes, and for another three minutes after adding the water. Cubes of $100 \mathrm{~mm}$ edge for compressive strength tests were cast and compacted in two layers on a vibrating table, where each layer was vibrated for 10 seconds. The moulds were covered with polyethylene sheets and moistened for 24 hours. Then the specimens were demoulded and cured in water (N-W series) and saturated limewater (N-LW series) at a temperature of $20{ }^{\circ} \mathrm{C}$ prior to test days. To produce saturated limewater, the lime powder was solved in fresh water and distilled until the excess lime powder was precipitated. The strength tests of the cementitious composite samples were determined at 7, 28 and 90 days after curing. After each time of the curing, the old limewater media was replaced by a new one to maintain saturated limewater.
Table 2. The properties of nano- $\mathrm{ZrO}_{2}$.

\begin{tabular}{cccc}
\hline $\begin{array}{c}\text { Diameter } \\
(\mathbf{n m})\end{array}$ & $\begin{array}{c}\text { Surface volume ratio, } \\
\mathbf{m}^{\mathbf{2}} \cdot \mathbf{g}^{-\mathbf{1}}\end{array}$ & $\begin{array}{c}\text { Density, } \\
\mathbf{g} \cdot \mathbf{c m}^{-\mathbf{3}}\end{array}$ & $\begin{array}{c}\text { Purity } \\
(\boldsymbol{\%})\end{array}$ \\
\hline $15 \pm 3$ & $155 \pm 12$ & $<0.12$ & $>99.9$ \\
\hline
\end{tabular}

Table 3. Mixture proportion of nano- $\mathrm{ZrO}_{2}$ particles blended concretes.

\begin{tabular}{lccc}
\hline \multirow{2}{*}{$\begin{array}{c}\text { Sample } \\
\text { designation }\end{array}$} & \multirow{2}{*}{$\begin{array}{c}\text { nano- } \mathbf{Z r O}_{2} \\
\text { particles }\end{array}$} & \multicolumn{2}{c}{ Quantities, kg.m ${ }^{-3}$} \\
\cline { 3 - 4 } & & Cement & nano- $\mathbf{Z r O}_{2}$ particles \\
\hline C0 (control) & 0 & 450 & 0 \\
N1 & 0.5 & 447.75 & 2.25 \\
N2 & 1.0 & 445.50 & 4.50 \\
N3 & 1.5 & 443.25 & 6.75 \\
N4 & 2.0 & 441.00 & 9.00 \\
\hline
\end{tabular}

Water to binder [cement + nano- $\mathrm{ZrO}_{2}$ ] ratio of 0.40 , sand $492 \mathrm{~kg} \cdot \mathrm{m}^{-3}$, and aggregate $1148 \mathrm{~kg} \cdot \mathrm{m}^{-3}$.

Compressive strength of nano- $\mathrm{ZrO}_{2}$ particles blended cement cementitious composite cubes was determined in accordance to the ASTM C 39 ${ }^{[40]}$ after 7, 28 and 90 days of moisture curing. Tests were carried out on triplicate specimens and average compressive strength values were considered.

Mercury intrusion porosimetry (MIP) is extensively used to characterize the pore structure in porous material as a result of its simplicity, quickness and wide measuring range of pore diameter ${ }^{41,42}$. MIP provides information about the connectivity of pores ${ }^{41}$. In this study, the pore structure of concrete is evaluated by using MIP. To prepare the samples for MIP measurement, the concrete specimens after 90 days of curing are first broken into smaller pieces, and then the cement paste fragments selected from the center of prisms are used to measure pore structure. The samples are immersed in acetone to stop hydration as fast as possible. Before mercury intrusion test, the samples are dried in an oven at about $110^{\circ} \mathrm{C}$ until constant weight to remove moisture in the pores. MIP is based on the assumption that the non-wetting liquid mercury (the contact angle between mercury and solid is greater than $90^{\circ}$ ) will only intrude in the pores of porous material under pressure ${ }^{41,42}$. Each pore size is quantitatively determined from the relationship between the volume of intruded mercury and the applied pressure ${ }^{42}$. The relationship between the pore diameter and applied pressure is generally described by Washburn Equation 1 as follows ${ }^{41,42}$ :

$D=-4 \gamma \cos \theta / P$

where, $D$ is the pore diameter (nm), $\gamma$ is the surface tension of mercury (dyne/cm), $\theta$ is the contact angle between mercury and solid $\left(^{\circ}\right)$ and $P$ is the applied pressure $(\mathrm{MPa})$. The test apparatus used for pore structure measurement is Auto Pore III mercury porosimeter. Mercury density is $13.5335 \mathrm{~g}$. 
$\mathrm{mL}^{-1}$. The surface tension of mercury is taken as 485 dynes. $\mathrm{cm}^{-1}$, and the contact angle selected is $130^{\circ}$. The maximum measuring pressure applied is $200 \mathrm{MPa}$ (30000 psi), which means that the smallest pore diameter that can be measured reaches about $6 \mathrm{~nm}$ (on the assumption that all pores have cylindrical shape).

Conduction calorimetry test was run out on a Wexham Developments JAF model isothermal calorimeter, using IBM program AWCAL-4, at $22{ }^{\circ} \mathrm{C}$ for a maximum of 70 hours. Fifteen grams of cement was mixed with water and saturated limewater and admixture before introducing it into the calorimeter cell.

A Netzsch model STA 409 simultaneous thermal analyzer equipped with a Data Acquisition System 414/1 programmer was used for thermogravimetric analysis. Specimens which were cured in water and saturated limewater for 90 days were heated from 110 to $650{ }^{\circ} \mathrm{C}$, at a heating rate of $4{ }^{\circ} \mathrm{C} / \mathrm{min}$ in an inert $\mathrm{N}_{2}$ atmosphere.

SEM investigations were conducted on a Hitachi apparatus. Backscattered electron (BSE) and secondary electron (SE) imaging was used to study the samples, which were prepared under conditions that ensured their subsequent viability for analytical purposes.

A Philips PW-1730 unit was used for XRD analysis which was taken from 4 to $70^{\circ}$.

\section{Results and Discussion}

\subsection{Compressive strength}

The compressive strength results of $\mathrm{C} 0-\mathrm{W}$ and $\mathrm{N}-\mathrm{W}$ series mixtures are shown in Table 4. By comparison the compressive strength of the specimens cured for 7, 28 and 90 days, it could be observed that the compressive strength increases with nano- $\mathrm{ZrO}_{2}$ particles up to $1.0 \%$ replacement (N2-W) and then it decreases, although adding $2.0 \%$ nanoparticles (N4-W) results in strengths which are still higher than those of the plain cement concrete $(\mathrm{C} 0-\mathrm{W})$. It was shown that using $2.0 \%$ nano- $\mathrm{ZrO}_{2}$ particles in $\mathrm{N}-\mathrm{W}$ series decreases the compressive strength to a value which is near to the control cementitious composite. This may be due to the defects generated in dispersion of nanoparticles that

Table 4. Compressive strength of nano- $\mathrm{ZrO}_{2}$ particle blended cement mortars.

\begin{tabular}{lcccc}
\hline \multirow{2}{*}{$\begin{array}{c}\text { Sample } \\
\text { designation }\end{array}$} & $\begin{array}{c}\text { nano- } \\
\text { particle }(\%)\end{array}$ & \multicolumn{3}{c}{ Compressive strength, MPa } \\
\cline { 3 - 5 } & 0 & 27.3 & 36.8 & 42.3 \\
\hline C0-W (control) & 0 & 30 & 40.5 & 44.1 \\
N1-W & 0.5 & 31.4 & 41.4 & 45.6 \\
N2-W & 1.0 & 30.5 & 40.7 & 45.3 \\
N3-W & 1.5 & 27 & 37.7 & 42 \\
N4-W & 2.0 & 27 & 35.4 & 39.8 \\
C0-LW (control) & 0 & 30.4 & 45.6 & 46 \\
N1-LW & 0.5 & 33.7 & 47.8 & 48.4 \\
N2-LW & 1.0 & 36.9 & 51.1 & 51.4 \\
N3-LW & 1.5 & 39.9 & 53.4 & 53.5 \\
N4-LW & 2.0 & &
\end{tabular}

Water to binder [cement + nano- $\mathrm{ZrO}_{2}$ ] ratio of 0.40 . W denotes the specimens cured in water and LW denotes to those cured in saturated limewater. causes weak zones. The high enhancement of compressive strength in the $\mathrm{N}$ series blended cementitious composite are due to the rapid consuming of $\mathrm{Ca}(\mathrm{OH})_{2}$ which was formed during hydration of Portland cement specially at early ages related to the high reactivity of nano- $\mathrm{ZrO}_{2}$ particles. As a consequence, the hydration of cement is accelerated and larger volumes of reaction products are formed. Also nano- $\mathrm{ZrO}_{2}$ particles recover the particle packing density of the blended cement, directing to a reduced volume of larger pores in the cement paste. Figures 1 and 2 respectively show the SEM micrograph of concrete without and with $\mathrm{ZrO}_{2}$ nanoparticles after 7 days of curing in water. $\mathrm{C}-\mathrm{S}-\mathrm{H}$ gel which is existed in isolation is enclosed by some of needle-hydrates in the SEM micrograph of cement paste (Figure 1). On the other hand, the micrograph of the mixture containing nano- $\mathrm{ZrO}_{2}$ revealed a compact formation of hydration products and a reduced content of $\mathrm{Ca}(\mathrm{OH})_{2}$ crystals (Figure 2). In addition XRD results of the cement pastes with and without $\mathrm{ZrO}_{2}$ nanoparticles after 15 hours of curing in water has been illustrated in Figure 3. The results show that after 15 hours of curing, $\mathrm{Ca}(\mathrm{OH})_{2}$ crystals appears in concrete with $\mathrm{ZrO}_{2}$ nanoparticles while in concrete specimens without $\mathrm{ZrO}_{2}$ nanoparticles they do not appear indicating synergic effects of $\mathrm{ZrO}_{2}$ nanoparticles on formation of subsequent C-S-H gel

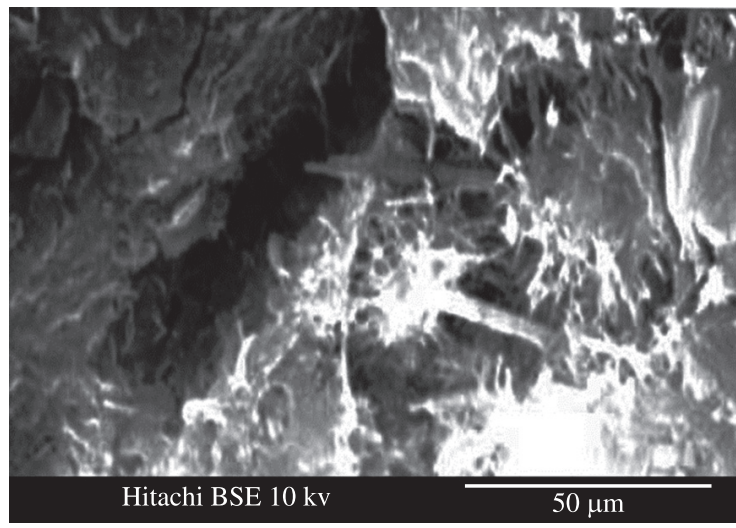

Figure 1. SEM micrograph of cement paste without $\mathrm{ZrO}_{2}$ nanoparticles.

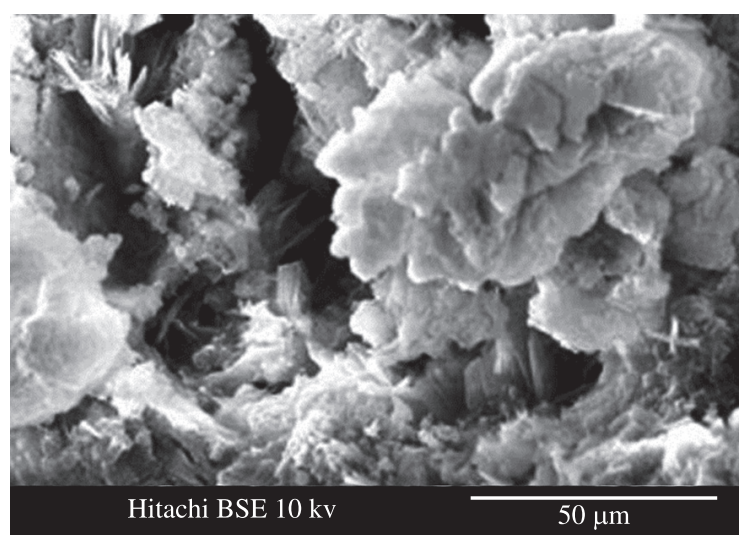

Figure 2. SEM micrograph of cement paste with $\mathrm{ZrO}_{2}$ nanoparticles cured in water 
Table 4 also shows the compressive strength of $\mathrm{C} 0$-LW and N-LW series. The results show that the replacement of cement by $\mathrm{ZrO}_{2}$ nanoparticles up to $2.0 \mathrm{Wt} \%$ (N4-LW) in $\mathrm{N}-\mathrm{LW}$ series produces cementitious composite with high strength with respect to N-LW cementitious composite. By comparison the compressive strength of $\mathrm{C} 0-\mathrm{W}$ and $\mathrm{C} 0-\mathrm{LW}$ series, it is seen that after 7, 28 and 90 days of curing, the compressive strength of the $\mathrm{C} 0-\mathrm{LW}$ series is smaller than the corresponding strength of $\mathrm{C} 0-\mathrm{W}$ series. This may be due to more formation of crystalline $\mathrm{Ca}(\mathrm{OH})_{2}$ in limewater which reduces the compressive strength of $\mathrm{C} 0$-LW series with respect to $\mathrm{C} 0-\mathrm{W}$ series. On the other hand, the compressive strength of N-LW series is more than those of N-W series. Lime reacts with water and produces $\mathrm{Ca}(\mathrm{OH})_{2}$ which needs to form strengthening gel$^{43}$ (Equation 2):

$\mathrm{CaO}+\mathrm{H}_{2} \mathrm{O}=\mathrm{Ca}(\mathrm{OH})_{2}+$ Heat

when $\mathrm{ZrO}_{2}$ nanoparticles react with $\mathrm{Ca}(\mathrm{OH})_{2}$ produced from saturated limewater, the content of strengthening gel is increased because of high free energy of nanoparticles ${ }^{28,29,38}$. The compressive strength of N-W and N-LW series should be compared from two viewpoints:

1) The compressive strength of N-LW series increases by partial replacement of cement with $\mathrm{ZrO}_{2}$ nanoparticles up to $2.0 \mathrm{wt} \%$ (N4-LW) while for $\mathrm{N}-\mathrm{W}$ series it increases by replacement level up to $1.0 \mathrm{wt} \%(\mathrm{~N} 2-\mathrm{W})$ and then decreases. Once more this confirms the more strengthening gel formation in the presence of saturated limewater in which the quantity of nano- $\mathrm{ZrO}_{2}$ particles present in the mix is close to the amount required to combine with the liberated lime during the process of hydration ${ }^{28,29,38}$.

2) The difference between compressive strengths of the $\mathrm{N}-\mathrm{W}$ and N-LW series after 28 days of curing is relatively high while this difference after 90 days of curing is not high. This may be due to formation of crystalline $\mathrm{Ca}(\mathrm{OH})_{2}$ in N-LW series after 28 days. In the other words, curing of the $\mathrm{ZrO}_{2}$ nanoparticles blended cementitious composite in

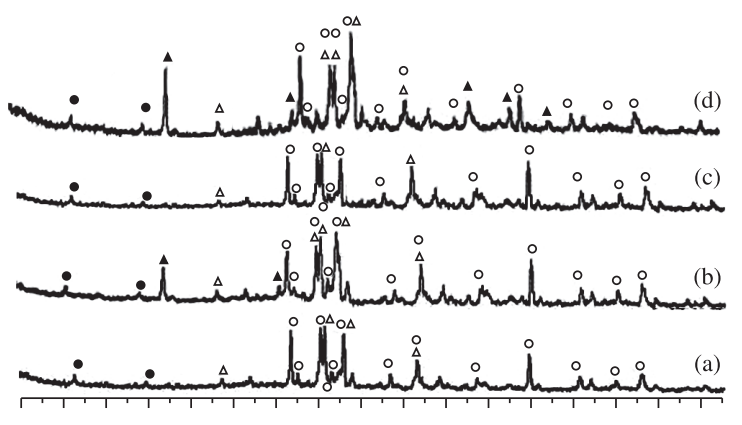

$\begin{array}{lllllllllllllllll}4 & 8 & 12 & 16 & 20 & 24 & 28 & 32 & 36 & 40 & 44 & 48 & 52 & 56 & 60 & 64 & 68\end{array}$

$2 \theta$

$$
\text { - } \mathrm{Ca}_{3} \mathrm{SlO}_{5} \Delta \mathrm{Ca}_{2} \mathrm{SlO}_{4} \Delta \mathrm{Ca}(\mathrm{OH})_{2} \text { - Etringite }
$$

Figure 3. XRD results of cement pastes at 15 hours of curing for specimens a) without $\mathrm{ZrO}_{2}$ nanoparticles cured in water; b) with $\mathrm{ZrO}_{2}$ nanoparticles cured in water; c) without $\mathrm{ZrO}_{2}$ nanoparticles cured in saturated limewater and d) with $\mathrm{ZrO}_{2}$ nanoparticles cured in saturated limewater. saturated limewater after 28 days is completely suitable to achieve high strength especially with high weight percent of nanoparticles.

Figures 4 and 5 show the SEM micrograph of concrete without and with $\mathrm{ZrO}_{2}$ nanoparticles at 7 days of curing in saturated limewater. The micrograph of the mixture containing nano- $\mathrm{ZrO}_{2}$ revealed a compact formation of hydration products and a reduced content of $\mathrm{Ca}(\mathrm{OH})_{2}$ crystals. Moreover, No significant differences is evident between the microstructure of concrete without nano$\mathrm{ZrO}_{2}$ cured in water or saturated limewater. In addition $\mathrm{XRD}$ results of the cement pastes with $\mathrm{ZrO}_{2}$ nanoparticles at 15 hours of curing in saturated limewater have been illustrated in Figure 2. The longer pick intensity show that the amount of $\mathrm{Ca}(\mathrm{OH})_{2}$ crystals which needs to formation $\mathrm{C}-\mathrm{S}-\mathrm{H}$ gel is more for the specimens cured in limewater rather than the specimens cured in water when $\mathrm{ZrO}_{2}$ nanoparticles are used.

\subsection{Pore structure of concrete}

The pore structure of concrete is the general embodiment of porosity, pore size distribution, pore scale and pore geometry. The test results of MIP in this study include the pore structure parameters such as total specific pore volume,

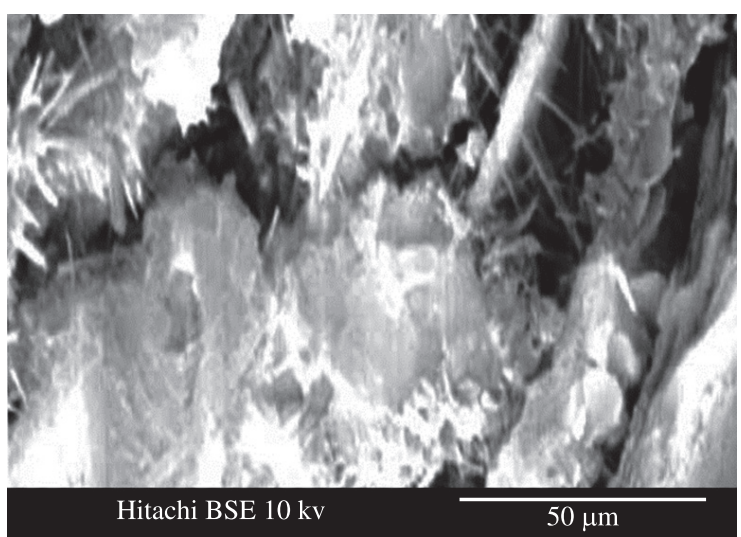

Figure 4. SEM micrograph of cement paste without $\mathrm{ZrO}_{2}$ nanoparticles cured in saturated limewater.

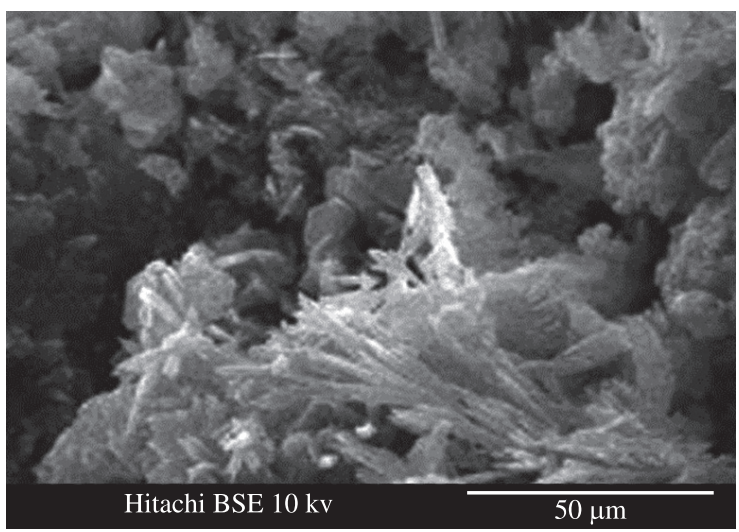

Figure 5. SEM micrograph of cement paste with $\mathrm{ZrO}_{2}$ nanoparticles cured in saturated limewater. 
most probable pore diameter, pore size distribution, porosity, average diameter, and median diameter (volume).

In terms of the different effect of pore size on concrete performance, the pore in concrete is classified as harmless pore $(<20 \mathrm{~nm})$, few-harm pore $(20 \sim 50 \mathrm{~nm})$, harmful pore $(50 \sim 200 \mathrm{~nm})$ and multi-harm pore $(>200 \mathrm{~nm})^{[44]}$. In order to analyze and compare conveniently, the pore structure of concrete is divided into four ranges according to this sort method in this work.

\subsubsection{Total specific pore volume and most probable pore diameter of concrete}

Table 5 shows that with the addition of $\mathrm{ZrO}_{2}$ nanoparticles, the total specific pore volumes of concretes is decreased, and the most probable pore diameters of concretes shift to smaller pores and fall in the range of few-harm pore, which indicates that the addition of nanoparticles refines the pore structure of concretes.

The effectiveness of nano- $\mathrm{ZrO}_{2}$ in reducing the total specific pore volumes and most probable

Table 5. Total specific pore volumes and most probable pore diameters of concretes.

\begin{tabular}{|c|c|c|c|c|}
\hline \multirow[t]{2}{*}{$\begin{array}{l}\text { Mixture } \\
\text { type }\end{array}$} & \multicolumn{2}{|c|}{$\begin{array}{l}\text { Total specific } \\
\text { pore volume }\end{array}$} & \multicolumn{2}{|c|}{$\begin{array}{l}\text { Most probable } \\
\text { pore diameter }\end{array}$} \\
\hline & $\begin{array}{c}\text { Value } \\
\left(\mathbf{m L} \cdot \mathbf{g}^{-1}\right)\end{array}$ & $\begin{array}{c}\text { Reduced } \\
\text { extent }(\%)\end{array}$ & $\begin{array}{l}\text { Value } \\
(\mathbf{n m})\end{array}$ & $\begin{array}{c}\text { Reduced } \\
\text { extent }(\%)\end{array}$ \\
\hline $\mathrm{C} 0-\mathrm{W}$ (control) & 0.0481 & 0 & 42 & 0 \\
\hline N1-W & 0.0446 & +7.12 & 34 & +19.05 \\
\hline N2-W & 0.0451 & +6.18 & 35 & +16.67 \\
\hline N3-W & 0.0455 & +5.24 & 36 & +14.29 \\
\hline N4-W & 0.0460 & +4.31 & 39 & +7.14 \\
\hline C0-LW (control) & 0.0466 & 0 & 40 & 0 \\
\hline N1-LW & 0.0426 & +8.69 & 30 & +25 \\
\hline N2-LW & 0.0431 & +7.53 & 31 & +22.5 \\
\hline N3-LW & 0.0437 & +6.18 & 34 & +15 \\
\hline N4-LW & 0.0442 & +5.21 & 36 & +10 \\
\hline
\end{tabular}

Water to binder [cement + nano- $\mathrm{ZrO}_{2}$ ] ratio of 0.40 . W denotes the specimens cured in water and LW denotes to those cured in saturated limewater. pore diameters of concretes increases in the order $\mathrm{N} 4-\mathrm{W}<\mathrm{N} 1-\mathrm{W}<\mathrm{N} 3-\mathrm{W}<\mathrm{N} 2-\mathrm{W}$ series for the specimens cured in water and N1-LW $<$ N2-LW $<$ N3-LW $<$ N4-LW for the specimens cured in saturated limewater.

With increasing the content of nanoparticles, the reduced extent of total specific pore volume and most probable pore diameter increases, and the refinement on the pore structure of concretes is improved.

Table 6 gives the porosities, average diameters and median diameters (volume) of various concretes. The regularity of porosity is similar to that of total specific pore volume. The regularity of average diameter and median diameter (volume) is similar to that of most probable pore diameter. Therefore, it is no longer necessary to analyze one by one herein.

\subsubsection{Pore size distribution of concrete}

The pore size distribution of concretes is shown in Table 7. It can be seen that by the addition of nano-particles, the amounts of pores decrease, which shows that the density of concretes is increased and the pore structure is improved.

The effectiveness of nano- $\mathrm{ZrO}_{2}$ in improving the pore structure of concretes increases in the order $\mathrm{N} 4-\mathrm{W}<\mathrm{N} 1-\mathrm{W}<\mathrm{N} 3-\mathrm{W}<\mathrm{N} 2-\mathrm{W}$ series for the specimens cured in water and N1-LW $<$ N2-LW $<$ N3-LW $<$ N4-LW for the specimens cured in saturated limewater.

The harmless and few-harm pores in N2-W and N4LW series increase by the largest extent, while its harmful and multi-harm pores decrease by the largest extent, which indicates that the pore structure of N2-W and N4-LW series is most significantly improved. With increasing of nanoparticles' content, the extent pores in concretes are all decreased, and the improvement on the pore structure of concretes is evident.

The mechanism that the nanoparticles improve the pore structure of concrete can be interpreted as follows. Supposed that nanoparticles are uniformly dispersed in concrete and each particle is contained in a cube pattern, the distance between nanoparticles can be determined. After hydration begins, hydrate products diffuse and envelop nanoparticles as kernel. If the content of nanoparticles and the distance

Table 6. Prosities, average diameters and median diameters (volume) of concretes.

\begin{tabular}{|c|c|c|c|c|c|c|}
\hline \multirow{2}{*}{$\begin{array}{c}\text { Mixture } \\
\text { type }\end{array}$} & \multicolumn{2}{|c|}{ Prosity } & \multicolumn{2}{|c|}{ Average diameter } & \multicolumn{2}{|c|}{ Median diameter (volume) } \\
\hline & $\begin{array}{c}\text { Value } \\
(\%)\end{array}$ & $\begin{array}{c}\text { Reduced extent } \\
(\%)\end{array}$ & $\begin{array}{r}\text { Value } \\
(\mathbf{n m})\end{array}$ & $\begin{array}{c}\text { Reduced extent } \\
(\%)\end{array}$ & $\begin{array}{l}\text { Value } \\
(\mathbf{n m})\end{array}$ & $\begin{array}{c}\text { Reduced extent } \\
(\%)\end{array}$ \\
\hline $\mathrm{C} 0-\mathrm{W}$ (control) & 9.99 & 0 & 37.53 & 0 & 51.4 & 0 \\
\hline N1-W & 9.01 & +8.84 & 31.9 & +13.60 & 42.5 & +15.60 \\
\hline $\mathrm{N} 2-\mathrm{W}$ & 9.30 & +6.24 & 34.0 & +8.42 & 44.8 & +11.51 \\
\hline N3-W & 9.46 & +4.78 & 35.6 & +4.75 & 47.9 & +6.15 \\
\hline N4-W & 9.56 & +3.89 & 37.1 & +1.08 & 50.4 & +1.73 \\
\hline $\mathrm{C} 0$-LW (control) & 9.66 & 0 & 34.2 & 0 & 48.7 & 0 \\
\hline N1-LW & 8.20 & +13.59 & 30.1 & +10.89 & 40.1 & +15.97 \\
\hline N2-LW & 8.42 & +11.49 & 32.3 & +4.97 & 42.4 & +11.65 \\
\hline N3-LW & 8.70 & +8.89 & 33.0 & +3.08 & 44.3 & +8.15 \\
\hline N4-LW & 8.90 & +7.046 & 35.4 & -3.08 & 47.9 & +1.50 \\
\hline
\end{tabular}

Water to binder [cement + nano- $\mathrm{ZrO}_{2}$ ] ratio of 0.40 . W denotes the specimens cured in water and $\mathrm{LW}$ denotes to those cured in saturated limewater. 
Table 7. Pore size distribution of concretes.

\begin{tabular}{|c|c|c|c|c|c|}
\hline \multirow{2}{*}{$\begin{array}{l}\text { Mixture } \\
\text { type }\end{array}$} & \multicolumn{4}{|c|}{ Pore size distribution $\left(\mathrm{mL} \cdot \mathrm{g}^{-1}(\%)\right)$} & \multirow{2}{*}{$\begin{array}{l}\text { Total specific pore } \\
\text { volume }\left(\mathrm{mL} \cdot \mathrm{g}^{-1}\right)\end{array}$} \\
\hline & $\begin{array}{l}\text { Harmless pores } \\
\qquad(<\mathbf{2 0} \mathbf{~ n m})\end{array}$ & $\begin{array}{c}\text { Few-harm pores } \\
(20 \sim 50 \mathrm{~nm})\end{array}$ & $\begin{array}{l}\text { Harmful pores } \\
(50 \sim 200 \mathrm{~nm})\end{array}$ & $\begin{array}{l}\text { Multi-harm pores } \\
\quad(>200 \mathbf{~ n m})\end{array}$ & \\
\hline $\mathrm{C} 0-\mathrm{W}$ (control) & 0.0065 & 0.0147 & 0.0169 & 0.0099 & 0.0481 \\
\hline N1-W & 0.0066 & 0.0166 & 0.0141 & 0.0076 & 0.0446 \\
\hline $\mathrm{N} 2-\mathrm{W}$ & 0.0067 & 0.0161 & 0.0148 & 0.0080 & 0.0451 \\
\hline N3-W & 0.0068 & 0.0156 & 0.0154 & 0.0085 & 0.0455 \\
\hline N4-W & 0.0068 & 0.0151 & 0.0158 & 0.0089 & 0.0460 \\
\hline C0-LW (control) & 0.0067 & 0.0157 & 0.0148 & 0.0091 & 0.0466 \\
\hline N1-LW & 0.0069 & 0.0175 & 0.0122 & 0.0064 & 0.0426 \\
\hline N2-LW & 0.0069 & 0.0170 & 0.0128 & 0.0068 & 0.0431 \\
\hline N3-LW & 0.0069 & 0.0166 & 0.0140 & 0.0071 & 0.0437 \\
\hline N4-LW & 0.0070 & 0.0160 & 0.0142 & 0.0075 & 0.0442 \\
\hline
\end{tabular}

Water to binder [cement + nano- $\mathrm{ZrO}_{2}$ ] ratio of 0.40 . W denotes the specimens cured in water and $\mathrm{LW}$ denotes to those cured in saturated limewater.

between them are appropriate, the crystallization will be controlled to be a suitable state through restricting the growth of $\mathrm{Ca}(\mathrm{OH})_{2}$ crystal by nanoparticles. Moreover, the nanoparticles located in cement paste as kernel can further promote cement hydration due to their high activity. This makes the cement matrix more homogeneous and compact. Consequently, the pore structure of concrete is improved evidently such as the concrete containing nano- $\mathrm{ZrO}_{2}$ in the amount of $2.0 \%$ by weight of nanoparticles.

With increasing content of nanoparticles, the improvement on the pore structure of concrete is evident. This can be attributed to that the distance between nanoparticles decreases with increasing content of nanoparticles, and $\mathrm{Ca}(\mathrm{OH})_{2}$ crystal cannot grow up enough due to limited space and the crystal quantity is decreased, which leads to the ratio of crystal to strengthening gel small and the shrinkage and creep of cement matrix is decreased ${ }^{44}$, thus the pore structure of cement matrix is better relatively.

On the whole, the addition of nanoparticles improves the pore structure of concrete. On the one hand, nanoparticles can act as a filler to enhance the density of concrete, which leads to the porosity of concrete reduced significantly. On the other hand, nanoparticles can not only act as an activator to accelerate cement hydration due to their high activity, but also act as a kernel in cement paste which makes the size of $\mathrm{Ca}(\mathrm{OH})_{2}$ crystal smaller and the tropism more stochastic.

\subsection{Conduction calorimetry}

Two signals can be distinguished on all test results: a peak corresponding to the acceleration or post-induction period, associated with the precipitation of $\mathrm{C}-\mathrm{S}-\mathrm{H}$ gel and $\mathrm{CH}$, and a shoulder related to a second, weaker signal with a later peak time, associated with the transformation from the ettringite $(\mathrm{AFt})$ to the calcium monosulphoaluminate (AFm) phase via dissolution and reaction with $\mathrm{Al}(\mathrm{OH})^{4-[45]}$. The numerical values corresponding to these two signals (heat release rate, peak times) and the total released heat are shown in Table 8 . The time period over the total heat was measured until the heat release rate was below $1 \%$ of the maximum of the second peak.
Table 8. Calorimetric results of cement pastes.

\begin{tabular}{|c|c|c|c|c|c|}
\hline \multirow[t]{2}{*}{ Mixture } & \multirow{2}{*}{$\begin{array}{c}\begin{array}{c}\text { Total } \\
\text { heat }\end{array} \\
{\mathrm{kJ} . \mathrm{kg}^{-1}}^{-}\end{array}$} & \multicolumn{2}{|c|}{$\begin{array}{l}\text { First } \\
\text { peak }\end{array}$} & \multicolumn{2}{|c|}{$\begin{array}{c}\text { Second } \\
\text { peak }\end{array}$} \\
\hline & & $\begin{array}{c}\text { Time } \\
\text { (hours) }\end{array}$ & $\begin{array}{c}\text { Rate } \\
\left(\mathbf{W} \cdot \mathbf{k g}^{-1}\right)\end{array}$ & $\begin{array}{c}\text { Time } \\
\text { (hours) }\end{array}$ & $\begin{array}{c}\text { Rate } \\
\left(\mathbf{W}^{\prime} \mathbf{k g}^{-1}\right)\end{array}$ \\
\hline $\mathrm{C} 0-\mathrm{W}$ (control) & 299.8 & 1.4 & 0.6 & 15.1 & 2.5 \\
\hline N1-W & 298.2 & 1.3 & 0.6 & 15.8 & 2.7 \\
\hline $\mathrm{N} 2-\mathrm{W}$ & 273.5 & 1.1 & 0.6 & 14 & 2.4 \\
\hline N3-W & 281.1 & 1.2 & 0.6 & 15.1 & 2.5 \\
\hline N4-W & 309.2 & 1.4 & 0.6 & 16.2 & 2.7 \\
\hline C0-LW (control) & 312.5 & 1.6 & 0.6 & 15.8 & 2.6 \\
\hline N1-LW & 290.9 & 1.6 & 0.6 & 15 & 2.4 \\
\hline N2-LW & 269.5 & 1.5 & 0.6 & 13 & 2.2 \\
\hline N3-LW & 254.7 & 1.3 & 0.5 & 11.2 & 2.2 \\
\hline N4-LW & 232.2 & 1 & 0.5 & 9.7 & 2 \\
\hline
\end{tabular}

Water to binder [cement + nano- $\mathrm{ZrO}_{2}$ ] ratio of 0.40 . W denotes the specimens cured in water and LW denotes to those cured in saturated limewater.

Table 9. Weight loss (\%) of the pastes in the range of $110-650{ }^{\circ} \mathrm{C}$ after 90 days of curing.

\begin{tabular}{lc}
\hline Mixture & Weight loss $(\%)$ \\
\hline C0-W (control) & 12.2 \\
N1-W & 14 \\
N2-W & 14.2 \\
N3-W & 14.1 \\
N4-W & 13.9 \\
C0-LW (control) & 12.7 \\
N1-LW & 13.4 \\
N2-LW & 13.1 \\
N3-LW & 12.7 \\
N4-LW & 12.3 \\
\hline
\end{tabular}

Water to binder [cement + nano- $\mathrm{ZrO}_{2}$ ] ratio of 0.40 . W denotes the specimens cured in water and LW denotes to those cured in saturated limewater.

The heat release rate values in Table 8 show that decreasing the percentage of nanoparticles in the pastes retards peak times and raises heat release rate values. In addition, the specimens which have been cured in saturated 
limewater show a decreased peak time and heat release rate values with respect to the corresponding specimens cured in water. This is indicative of a delay in initial cement hydration due to lesser content of nanoparticles and the lesser content of $\mathrm{Ca}(\mathrm{OH})_{2}$ in the specimens cured in water. The retardation is much less marked in the second peak. The total heat released under identical conditions (at times when the heat release rate is less than $1 \%$ of the maximum amount of heat released in the first peak) decreases with higher percentages of $\mathrm{ZrO}_{2}$ nanoparticles in the mix.

\subsection{Thermogravimetric analysis results}

Table 9 shows the weight loss measured in the 110$650{ }^{\circ} \mathrm{C}$ range in which dehydration of the hydrated products occurred. The results show that after 90 days of curing, the loss in weight of the specimens is increased by increasing the nanoparticles content in concretes. This is more evident in N2-W and N4-LW series. This may be due to more formation of hydrated C-S-H gel in N2-W and N4-LW series.

\section{References}

1. Bjornstrom J, Martinelli A, Matic A, Borjesson L and Panas I. Accelerating effects of colloidal nano-silica for beneficial calcium-silicate-hydrate formation in cement. Chemical Physics Letters. 2004; 392(1-3):242-8. http://dx.doi. org/10.1016/j.cplett.2004.05.071

2. Ji T. Preliminary study on the water permeability and microstructure of concrete incorporating nano-SiO2. Cement and Concrete Research. 2005; 35(10):1943-7. http://dx.doi. org/10.1016/j.cemconres.2005.07.004

3. Jo B-W, Kim C-H, Tae G-H and Park J-B. Characteristics of cement mortar with nano-SiO2 particles. Construction and Building Materials. 2007; 21(6):1351-5. http://dx.doi. org/10.1016/j.conbuildmat.2005.12.020

4. Li H, Xiao H-G and Ou J-P. A study on mechanical and pressure-sensitive properties of cement mortar with nanophase materials. Cement and Concrete Research. 2004; 34(3):435-8. http://dx.doi.org/10.1016/j.cemconres.2003.08.025

5. Li H, Zhang M-H and Ou J-P. Abrasion resistance of concrete containing nanoparticles for pavement. Wear. 2006; 260(1112):1262-6. http://dx.doi.org/10.1016/j.wear.2005.08.006

6. Qing Y, Zenan Z, Deyu K and Rongshen C. Influence of nano-SiO2 addition on properties of hardened cement paste as compared with silica fume. Construction and Building Materials. 2007; 21(3):539-45. http://dx.doi.org/10.1016/j. conbuildmat.2005.09.001

7. Lin KL, Chang WC, Lin DF, Luo HL and Tsai MC. Effects of nano-SiO2 and different ash particle sizes on sludge ash-cement mortar. Journal of Environmental Management. 2008; 88(4):708-14. PMid:17498863. http:// dx.doi.org/10.1016/j.jenvman.2007.03.036

8. Lin DF, Lin KL, Chang WC, Luo HL and Cai MQ. Improvements of nano-SiO2 on sludge/fly ash mortar. Waste Management. 2008; 28(6):1081-7. PMid:17512717. http:// dx.doi.org/10.1016/j.wasman.2007.03.023

9. Sobolev K, Flores I, Torres-Martinez LM, Valdez PL, Zarazua $\mathrm{E}$ and Cuellar EL. Engineering of $\mathrm{SiO} 2$ nanoparticles for

\section{Conclusions}

The results show that the specimens containing $\mathrm{ZrO}_{2}$ nanoparticles have significantly higher compressive strength with respect to the specimens without nano- $\mathrm{ZrO}_{2}$ at every age of curing. It is found that the cement could be advantageously replaced with nano- $\mathrm{ZrO}_{2}$ particles up to maximum limit of $2.0 \%$ with the average particle size of $15 \mathrm{~nm}$ when the specimens cured at saturated limewater. The optimum level of nano- $\mathrm{ZrO}_{2}$ particles content was achieved $1.0 \%$ for the specimens cured in water. $\mathrm{ZrO}_{2}$ nanoparticles could accelerate the appearance of the first peak in conduction calorimetry test which is related to the acceleration in formation of hydrated cement products. Thermogravimetric analysis shows that $\mathrm{ZrO}_{2}$ nanoparticles could increase the weight loss of the specimens when partially added to cement paste. More rapid formation of hydrated products in presence of $\mathrm{ZrO}_{2}$ nanoparticles which was confirmed by XRD results could be the reason of more weight loss. The pore structure of concrete containing $\mathrm{ZrO}_{2}$ nanoparticles is improved and the content of all mesopores and macropores is increased.

optimal performance in nano cementbased materials. In Bittnar Z, Bartos PJM, Nemecek J, Smilauer V and Zeman J. Nanotechnology in construction: proceedings of the NICOM3 ( $3^{\text {rd }}$ international symposium on nanotechnology in construction). Prague; 2009. p. 139-48.

10. Qing Y, Zenan Z, Li S and Rongshen C. A comparative study on the pozzolanic activity between nano-SiO2 and silica fume. Journal of Wuhan University of Technology - Materials Science Edition. 2008; 21(3):153-7.

11. Li H, Xiao H-G, Yuan J and Ou J. Microstructure of cement mortar with nanoparticles. Composites Part B: Engineering. 2004; 35(2):185-9. http://dx.doi.org/10.1016/ S1359-8368(03)00052-0

12. Chong KP and Garboczi EJ. Smart and designer structural material systems. Progress in Structural Engineering and Materials. 2002; 4:417-30. http://dx.doi.org/10.1002/pse.134

13. Gaitero JJ, Campillo I and Guerrero A. Reduction of the calcium leaching rate of cement paste by addition of silica nanoparticles. Cement and Concrete Research. 2008; 38(89):1112-8. http://dx.doi.org/10.1016/j.cemconres.2008.03.021

14. Jennings HM, Bullard JW, Thomas JJ, Andrade JE, Chen JJ and Scherer GW. Characterization and modeling of pores and surfaces in cement paste: correlations to processing and properties. Advanced Concrete Technology. 2008; 6(1):5-29. http://dx.doi.org/10.3151/jact.6.5

15. Scrivener KL and Kirkpatrick RJ. Innovation in use and research on cementitious material. Cement and Concrete Research. 2008; 38(2):128-36. http://dx.doi.org/10.1016/j. cemconres.2007.09.025

16. Scrivener KL. Nanotechnology and cementitious materials. In: Bittnar Z, Bartos PJM, Nemecek J, Smilauer V and Zeman J. Nanotechnology in construction: proceedings of the NICOM3 (3rd international symposium on nanotechnology in construction). Prague; 2009. p. 37-42.

17. Li H, Zhang MH and Ou JP. Flexural fatigue performance of concrete containing nano-nanoparticles for pavement. International Journal of Fatigue 2007; 29:1292-1301. http:// dx.doi.org/10.1016/j.ijfatigue.2006.10.004 
18. Li H, Zhang $\mathrm{MH}$ and $\mathrm{Ou}$ JP. Abrasion resistance of concrete containing nano-nanoparticles for pavement. Wear Journal. 2006; 260:1262-1266. http://dx.doi.org/10.1016/j. wear.2005.08.006

19. Katyal NK, Ahluwalia SC. and Ram P. Effect of TiO2 on the hydration of tricalcium silicate. Cement and Concrete Research. 1999; 29:1851-1855. http://dx.doi.org/10.1016/ S0008-8846(99)00171-4

20. Nazari A and Riahi S. Microstructural, thermal, physical and mechanical behavior of the self compacting concrete containing $\mathrm{SiO}_{2}$ nanoparticles. Materials Science and Engineering: A. 2010; 527:7663-7672. http://dx.doi.org/10.1016/j. msea.2010.08.095

21. Nazari A and Riahi S. The effect of $\mathrm{TiO}_{2}$ nanoparticles on water permeability and thermal and mechanical properties of high strength self-compacting concrete. Materials Science and Engineering: A. 2010; 528(2):756-763. http://dx.doi. org/10.1016/j.msea.2010.09.074

22. Nazari A. The effects of curing medium on flexural strength and water permeability of concrete incorporating $\mathrm{TiO}_{2}$ nanoparticles. Materials and Structures. 2011; 44(4):773-786. http://dx.doi.org/10.1617/s11527-010-9664-y

23. Nazari A and Riahi S. The effects of zinc dioxide nanoparticles on flexural strength of self-compacting concrete. Composites Part B: Engineering. 2011; 42:167-175. http://dx.doi. org/10.1016/j.compositesb.2010.09.001

24. Nazari A and Riahi S. Computer-aided prediction of physical and mechanical properties of high strength cementitious composite containing $\mathrm{Cr}_{2} \mathrm{O}_{3}$ nanoparticles. Nano. 2010; 5(5):301-318. http://dx.doi.org/10.1142/S1793292010002219

25. Nazari A and Riahi S. The effects of $\mathrm{SiO}_{2}$ nanoparticles on physical and mechanical properties of high strength self compacting concrete. Composites Part B: Engineering. 2011; 42:570-578. http://dx.doi.org/10.1016/j. compositesb.2010.09.025

26. Nazari A and Riahi S. Improvement compressive strength of cementitious composites in different curing media by A12O3 nanoparticles. Materials Science and Engineering: A. 2011; 528:1183-1191. http://dx.doi.org/10.1016/j. msea.2010.09.098

27. Nazari A and Riahi S. The effects of $\mathrm{Cr}_{2} \mathrm{O}_{3}$ nanoparticles on strength assessments and water permeability of concrete in different curing media. Materials Science and Engineering: A. 2011; 528:1173-1182. http://dx.doi.org/10.1016/j. msea.2010.09.099

28. Nazari A and Riahi S. $\mathrm{ZrO}_{2}$ nanoparticles effects on split tensile strength of self compacting concrete. Materials Research. 2010; 13(4):485-495. http://dx.doi.org/10.1590/ S1516-14392010000400011

29. Nazari A and Riahi S. The effects of $\mathrm{ZrO}_{2}$ nanoparticles on physical and mechanical properties of high strength self compacting concrete. Materials Research. 2010; 13(4):551556. http://dx.doi.org/10.1590/S1516-14392010000400019

30. Nazari A and Riahi S. The effects of Zno2 nanoparticles on strength assessments and water permeability of concrete in different curing media. Materials Research, 2011; 14(2):178188. http://dx.doi.org/10.1590/S1516-14392011005000030
31. Nazari A and Riahi S. A12O3 nanoparticles in concrete and different curing media. Energy and Buildings. 2011; 43:14801488. http://dx.doi.org/10.1016/j.enbuild.2011.02.018

32. Riahi S and Nazari A. Physical, mechanical and thermal properties of concrete in different curing media containing ZnO2 nanoparticles. Energy and Buildings. 2011; 43:19771984. http://dx.doi.org/10.1016/j.enbuild.2011.04.009

33. Nazari A and Riahi S. Effects of $\mathrm{CuO}$ Nanoparticles on Microstructure, Physical, Mechanical and Thermal Properties of Self-Compacting Cementitious Composites. Journal of Materials Sciences and Technology. 2011;27(1):81-92. http:// dx.doi.org/10.1016/S1005-0302(11)60030-3

34. Nazari A and Riahi S. Splitting tensile strength of concrete using ground granulated blast furnace slag and $\mathrm{SiO} 2$ nanoparticles as binder. Energy and Buildings. 2011; 43:864872. http://dx.doi.org/10.1016/j.enbuild.2010.12.006

35. Nazari A and Riahi S. TiO2 nanoparticles effects on physical, thermal and mechanical properties of self compacting concrete with ground granulated blast furnace slag as binder. Energy and Buildings. 2011; 43:995-1002. http://dx.doi.org/10.1016/j. enbuild.2010.12.025

36. Nazari A and Riahi S. Optimization $\mathrm{ZnO} 2$ nanoparticles content in binary blended concrete to enhance high strength concrete. International Journal of Materials Research. 2011; 102(4):457463. http://dx.doi.org/10.3139/146.110497

37. Nazari A and Riahi S. CuO nanoparticles' effects on compressive strength of self compacting concrete. Sadhana - Academy Proceedings in Engineering Science. 2011; 36(3):371-391.

38. Nazari A and Riahi S. Physical and mechanical behavior of high strength self compacting concrete containing $\mathrm{ZrO} 2$ nanoparticles. International Journal of Materials Research. 2011; 102(5):560-571. http://dx.doi. org/10.3139/146.110509

39. American Society for Testing and Materials. ASTM C150: Standard Specification for Portland Cement, annual book of ASTM standards. Philadelphia: ASTM; 2001.

40. American Society for Testing and Materials. ASTM C39: Standard Test Method for Compressive Strength of Cylindrical Concrete Specimens, annual book of ASTM standards. Philadelphia: ASTM; 2001.

41. Abell AB, Willis KL and Lange DA. Mercury Intrusion Porosimetry and Image nalysis of Cement-Based Materials. Journal of Colloid and Interface Science 1999; 211:39-44. PMid:9929433. http://dx.doi.org/10.1006/jcis.1998.5986

42. Tanaka K and Kurumisawa K. Development of technique for observing pores in hardened cement paste. Cement and Concrete Research 2002; 32:1435-41. http://dx.doi. org/10.1016/S0008-8846(02)00806-2

43. Mostafa NY and Brown PW. Heat of hydration of high reactive pozzolans in blended cements: Isothermal conduction calorimetry. Thermochimica Acta. 2005; 435:162-167. http:// dx.doi.org/10.1016/j.tca.2005.05.014

44. Ye Q. The study and development of the nano-composite cement structure materials. New Building Materials. 2001; (1):4-6.

45. Jawed J, Skalny J and Young JF. Hydration of Portland Cement. Structure and Performance of Cements. In: Barnes P. Applied Science Publishers. Essex; 1983. p. 284-285. 